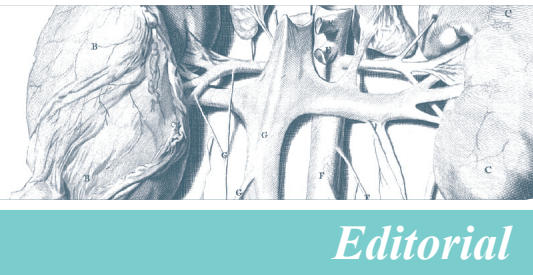

\title{
Manipulación, medios y métodos en la pandemia COVID-19
}

\author{
Mario Delgado-Noguera ${ }^{1}$
}

Durante la pandemia del COVID-19 ha habido cuestionamientos hacia el quehacer de la ciencia por parte de ciertos políticos, cuyas opiniones llevan a prácticas algunas veces sombrías y peligrosas para la salud de la población. La experiencia con este virus es nueva; aunque su conocimiento avanza, ha representado retos dado sus efectos a nivel global, en la salud pública, en lo económico y en lo social. A los políticos populistas les gustan los mensajes simples que penetren fácilmente o verdades a medias acordes con sus intereses y encantamientos que muestran como verdades, que muevan las emociones. La opinión informada debe mostrarse escéptica frente a esos mensajes.

Algunas personalidades del orden nacional o regional promueven tratamientos que aún no han sido probados de manera adecuada, o sea siguiendo los pasos rigurosos que son aceptados por la comunidad científica en el campo de la salud para probar, en el caso de la actual pandemia, medidas o intervenciones preventivas -como las vacunas-o tratamientos curativos para pacientes hospitalizados-como el plasma de convalecientes (1), el interferón (2) o la ivermectina (3)-. Estas intervencionesseprueban a través de diseńosepidemiológicos como los ensayos clínicos en los ambientes clínicos o los ensayos comunitarios en los contextos poblacionales. La epidemiología y sus métodos son la base de la investigación en la salud (4-5). Las vacunas deben cumplir además una serie de fases para asegurarse que no produzcan dańos; anuncios de efectividad sobre ellas sin cumplir aquellas fases, son engańosos y tienen fines particulares potencialmente dańinos para la población.

La pandemia COVID-19 ha hecho también que la ciencia ocupe un primer plano en los medios de comunicación. Recomendaciones como el uso de mascarilla, el distanciamiento social y el lavado de manos, hechas por los ministerios de salud u organizaciones como la OMS (6), se basan en evidencia científica que permite atenderlas con confianza. Algo similar pasó con el uso obligatorio del cinturón de seguridad para los autos, la prohibición de fumar en locales y sitios cerrados o el uso del casco para los motociclistas (7-10). Por lo tanto, el asesoramiento de los políticos y comunicadores por parte de los científicos es algo deseable y que poco a poco ha tomado fuerza para bien de la población. El llamado

1 Universidad del Cauca. Editor general de publicaciones. Área de desarrollo Editorial. 
que se les ha hecho a los politicos es a rodearse de científicos y especialistas para tomar decisiones adecuadas que tendrín con seguridad un gran impacto en la población, en su economía y en suporvenir.

La ciencia cumple con procesos en medio de la incertidumbre y la duda, puede realizar avances y retrocesos, valida pequeńos eventos que pueden tener efectos sobresalientes, rechaza prácticas que se creían saludables, cuestionando ella misma las supuestas verdades o evidencias a las que ha llegado. Los descubrimientos espectaculares, absolutos o milagrosos y las verdades fijas e inamovibles, son remanentes de épocas del romanticismo o del medievo y se conservan como anécdotas que han sido sembradas con éxito en el imaginario popular con su carga de subjetivismo radical. La humildad es también necesaria para quienes trabajan en la ciencia. Saber decir: 'aún no se conoce bien' o 'faltan pruebas' es una característica que da frescura al conocimiento humano donde la duda, la curiosidad y la pregunta son fundamentales e iluminan los caminos y los follajes del conocimiento.

En el ámbito médico, hay que tomar con mucha cautela a aquellos que, sin pruebas $n i$ estudios epidemiológicos, dicen que un tratamiento les hafuncionado bien. En los reportes de caso o series de caso (11), no se puede de ninguna manera hacer inferencia causal. Existen otros diseńos epidemiológicos que, por su misma estructura y capacidad para sobrellevar los sesgos y confusiones, permiten avanzar en conclusiones sobre causalidad.

Durante la pandemia también ha sido importante el acercamiento de la ciencia con la opinión pública, con el periodismo y con políticos que escuchan y que, a su vez, crean una confianza necesaria. Las páginas de los periódicos colombianos sobre divulgación científica eran escasas y se parecían más a recetarios de revistas del hogar. Ahora, con la pandemia, presentan tablas y gráficos con tendencias y se ha visto alguna inversión, aunque no suficiente, para hacer esa sección periodística atractiva e interactiva para el público lector, que en Colombia es desafortunadamente escaso.

Estas novedades y oportunidades que trae la pandemia son positivas, porque generan opinión informada que pone en tela de juicio las supuestas verdades, fake new o mensajes manipulados. La opinión informada, finalmente, permite diálogos de mayor altura y da lugar a preguntas más sólidas sobre esta y las pandemias que vendrán.

\section{REFERENCIAS}

1. Piechotta V, Chai KL, Valk SJ, Doree C, Monsef I, Wood EM, et al. Convalescent plasma or hyperimmune immunoglobulin for people with COVID-19: a living systematic review. Cochrane Database of Systematic Reviews 2020, Issue 7. Art. No. CD013600. https://doi. org/10.1002/14651858.CD013600.pub2

2. Cochrane Iberoamericana. ¿Es efectivo el interferón para el tratamiento de COVID-19? Evidencias COVID-19. Disponible en: https://es.cochrane.org/es/recursos/evidenciascovid-19. (Consultado el 5 de octubre de 2020).

3. Cochrane Iberoamericana. En los pacientes con diagnóstico de COVID-19 ¿se debe usar ivermectina como parte del tratamiento para reducir la progresión de la enfermedad o el riesgo de muerte? Evidencias COVID-19. Disponible en: https://es.cochrane.org/es/recursos/ evidencias-covid-19. (Consultado el 5 de octubre de 2020).

4. Shoemaker R, Delgado-Noguera M. Fundamentos de Epidemiología. 1ra. ed. Popayán: Editorial Universidad del Cauca; 2019 
5. Flórez ID, Sierra JM, Calvache JA. Evidence and decision-making in times of pandemic. Colomb. J. Anesthesiol. 2020; 48(4): e931. https://doi.org/10.5554/22562087.e931

6. WHO. Coronavirus disease (COVID-19) pandemic. Disponible en: https://www.who.int/ emergencies/diseases/novel-coronavirus-2019. (Consultado el 8 de octubre de 2020).

7. Dinh-Zarr TB, Sleet DA, Shults RA, Task Force on Community Preventive Services, et al. Reviews of evidence regarding interventions to increase the use of safety belts. Am J Prev Med. 2001;21 Suppl 4:48-65. https://doi.org/10.1016/S0749-3797(01)00378-6

8. Fouda Mbarga N, Abubakari AR, Aminde LN, Morgan AR. Seatbelt use and risk of major injuries sustained by vehicle occupants during motor-vehicle crashes: a systematic review and meta-analysis of cohort studies. BMC Public Health. 2018; 18(1):1413. https://doi. org/10.1186/s12889-018-6280-1

9. Peng Y, Vaidya N, Finnie R, Reynolds J, Dumitru C, Njie G, Elder R, Ivers R, Sakashita C, Shults RA, Sleet DA, Compton RP; Community Preventive Services Task Force. Universal Motorcycle Helmet Laws to Reduce Injuries: A Community Guide Systematic Review. Am J Prev Med. 2017; 52(6): 820-832. https://doi.org/10.1016/j.amepre.2016.11.030

10. Frazer K, Callinan JE, McHugh J, van Baarsel S, Clarke A, Doherty K, Kelleher C. Legislative smoking bans for reducing harms from secondhand smoke exposure, smoking prevalence and tobacco consumption. Cochrane Database of Systematic Reviews 2016, Issue 2. Art. No.: CD005992. https://doi.org/10.1002/14651858.CD005992.pub3

11. Delgado-Noguera M. Nuevas guías Para Reporte De Caso. Rev Fac Cienc Salud Univ Cauca. $2013 ; 15(3): 47-50$. 


\title{
Manipulation, media and methods in the COVID-19 pandemic
}

\author{
Mario Delgado-Noguera ${ }^{1}$
}

During the COVID-19 pandemic, there have been questions about the work of science by certain politicians whose opinions lead to practices that are sometimes shady and dangerous for the health of the population. The experience with this virus is new, although its knowledge is advancing, it has represented challenges given its effects at global level, in public health, economically and socially. Populist politicians prefer simple messages that penetrate easily or half-truths according to their interests and charms that they show as truths, that move the emotions. Informed opinion must be skeptical of these messages.

Some national or regional personalities promote treatments that have notyet been adequately tested, that is, following the rigorous steps that are accepted by the scientific community in the health field to test, in this case of the currentpandemic, measures or preventive interventions such as vaccines or curative treatments for hospitalized patients such as convalescent plasma (1), interferon (2) or ivermectin (3). The way to test these interventions is carried out through epidemiological designs such as clinical trials in clinical settings or community trials in population settings. Epidemiology and its methods are the basis of health research (4-5). Vaccines must also meet a series of phases to ensure that they do not cause harm; Advertisements of effectiveness on them without complying with those phases, are misleading and have particular and potentially harmfulpurposes for the population.

The COVID-19 pandemic has also brought science to the fore in the media. Use of the mask, social distancing, hand washing have behind their recommendation made by the ministries of health or health organizations such as the WHO (6), evidence to recommend their use with confidence. Something similar happened with the mandatory use of seat belts for cars, the prohibition of smoking in the premises and closed places or the use of helmets for motorcyclists (7-10). Therefore, the advice of politicians and journalist by scientists is something desirable and that little by little has gained strength for the good of the population. The call that has been made to politicians is to surround themselves with scientists and specialists to make adequate decisions that will surely have a great impact on the population, its economy and its future.

1 Universidad del Cauca. Editor general de publicaciones. Área de desarrollo Editorial. 
Science complies with processes in the midst of uncertainty and doubt, it can make advances and setbacks, validates small events that can have outstanding effects, rejects practices that were believed to be healthy, questioning the supposed truths or evidence that it has arrived at. The spectacular, absolute or miraculous discoveries and the fixed and immovable truths, are remnants of the romantic or medieval times and are preserved as anecdotes that have been successfully planted in the popular imagination with their load of radical subjectivism. Humility is also very necessary for those who work in science. Knowing how to say: 'it is not yet known well' or 'evidence is lacking' is a characteristic that gives freshness to human knowledge where doubt, curiosity and questions are fundamental and illuminate the paths and foliage of knowledge.

In the medical field, one must be taken with great caution those who, without evidence or epidemiological studies, say that a treatment has worked well for them. In case reports or case series (11), no causal inference can be made in any way. There are other epidemiological designs that, due to their structure and ability to deal with biases and confusion, allow us to advance conclusions about causality.

During the pandemic, the proximity between science with public opinion, with journalism and with politicians who listen and who, in turn, create a necessary trust has also been important. Pages of Colombian newspapers on popular science were scarce and looked more like cookbooks for home magazines. Now, with the pandemic, they present tables and graphs with trends and there has been some investment, not enough, to make this journalistic section one that is attractive and interactive for the reading public, which in Colombia is unfortunately scarce.

These news and opportunities brought by the pandemic are positive, because they generate informed opinion that calls into question the supposed truths, fake news or manipulated messages. Informed opinion, finally, allows for higher-level dialogues and raises stronger questions about this and the pandemics to come.

\section{REFERENCES}

1. Piechotta V, Chai KL, Valk SJ, Doree C, Monsef I, Wood EM, et al. Convalescent plasma or hyperimmune immunoglobulin for people with COVID』19: a living systematic review. Cochrane Database of Systematic Reviews 2020, Issue 7. Art. No.: CD013600. https://doi. org/10.1002/14651858.CD013600.pub2

2. Cochrane Iberoamericana. ¿Es efectivo el interferón para el tratamiento de COVID-19? Evidencias COVID-19. Disponible en: https://es.cochrane.org/es/recursos/evidenciascovid-19. (Consultado el 5 de octubre de 2020).

3. Cochrane Iberoamericana. En los pacientes con diagnóstico de COVID-19 ¿se debe usar ivermectina como parte del tratamiento para reducir la progresión de la enfermedad o el riesgo de muerte? Evidencias COVID-19. Disponible en: https://es.cochrane.org/es/recursos/ evidencias-covid-19. (Consultado el 5 de octubre de 2020).

4. Shoemaker R, Delgado-Noguera M. Fundamentos de Epidemiología. 1Ş. ed. Popayán: Editorial Universidad del Cauca; 2019

5. Flórez ID, Sierra JM, Calvache JA. Evidence and decision-making in times of pandemic. Colomb. J. Anesthesiol. 2020; 48(4):e931. https://doi.org/10.5554/22562087.e931 
6. WHO. Coronavirus disease (COVID-19) pandemic. Disponible en: https://www.who.int/ emergencies/diseases/novel-coronavirus-2019. (Consultado el 8 de octubre de 2020).

7. Dinh-Zarr TB, Sleet DA, Shults RA, Task Force on Community Preventive Services, et al. Reviews of evidence regarding interventions to increase the use of safety belts. Am J Prev Med. 2001;21 Suppl 4:48-65. https://doi.org/10.1016/S0749-3797(01)00378-6

8. Fouda Mbarga N, Abubakari AR, Aminde LN, Morgan AR. Seatbelt use and risk of major injuries sustained by vehicle occupants during motor-vehicle crashes: a systematic review and meta-analysis of cohort studies. BMC Public Health. 2018 Dec; 18(1): 1413. https://doi. org/10.1186/s12889-018-6280-1

9. Peng Y, Vaidya N, Finnie R, Reynolds J, Dumitru C, Njie G, Elder R, Ivers R, Sakashita C, Shults RA, Sleet DA, Compton RP; Community Preventive Services Task Force. Universal Motorcycle Helmet Laws to Reduce Injuries: A Community Guide Systematic Review. Am J Prev Med. 2017; 52(6): 820-832. https://doi.org/10.1016/j.amepre.2016.11.030

10. Frazer K, Callinan JE, McHugh J, van Baarsel S, Clarke A, Doherty K, Kelleher C. Legislative smoking bans for reducing harms from secondhand smoke exposure, smoking prevalence and tobacco consumption. Cochrane Database of Systematic Reviews 2016, Issue 2. Art. No.: CD005992. https://doi.org/10.1002/14651858.CD005992.pub3

11. Delgado-Noguera M. Nuevas guías Para Reporte De Caso. Rev Fac Cienc Salud Univ Cauca. 2013; 15(3):47-50. 